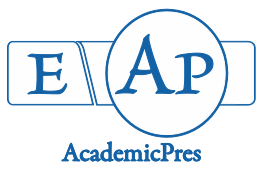

Saglam Ret al. (2020)

Notulae Scientia Biologicae 12(2):356-365

DOI: $10.15835 / \mathrm{nsb} 12210642$

Research Article

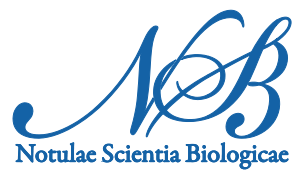

\title{
Comparative analysis of energy input-outputs of different tillage methods in second crop corn production
}

\author{
Ramazan SAGLAM, Leyla SEVEN, Ferhat KUP*
}

Harran University, Faculty of Agriculture, Department of Agricultural Machinery and Technologies Engineering, Sanliurfa, Turkey; saglamr@harran.edu.tr; leylaseven@windowslive.com (*correspondingauthor);ferkup63@harran.edu.tr

\begin{abstract}
In this study, conventional tillage (CT), reduced tillage (RT) and zero tillage (ZT) methods energy input-output analysis during second crop corn production have been carried out. The trials were performed between 2015-2016 in Ceylanpinar Directorate of Agricultural Enterprises Karatas region, Turkey. The findings showed that among tillage methods, the least energy input was ZT (23724.15 $\left.\mathrm{MJ} \mathrm{ha}^{-1}\right)$, and the most energy output was CT (138510 MJ ha- ${ }^{-1}$ ). In energy productivity, the highest value was on ZT (5.54). The highest value in corn yield was found in CT method with $9500 \mathrm{~kg}$ ha- 1 . This is followed by ZT ( $9100 \mathrm{~kg} \mathrm{ha}-1)$ and RT ( $8750 \mathrm{~kg}$ ha-1), respectively. As a result, although CT can be preferred due to its high yield, it has been observed that ZT and RT tillage methods should be supported especially due to its ecological and high energy productivity.
\end{abstract}

Keywords: corn; conventional tillage (CT); energy input-output; reduced tillage (RT); zero tillage (ZT)

\section{Introduction}

Three of the most important problems that the earth should tackle in the future are ensuring energy, water and food supply safety given that the energy is consumable, fossil fuels harm on ecology, works on alternative ecologist production techniques and productive usage of energy have great importance. Energy productivity is the first element of a sustainable global energy system. While providing environmental and social advantages, energy productivity can reduce climate change, enhance energy safety and boost the economy. One of the greatest inputs, especially in agricultural production, is energy. Iqbal (2007) stated in his work that during the transition from conventional agriculture to modern agriculture, commercialized energy usage acutely increased. Conservation agriculture (CA)-based systems play a vital role in sustainable agricultural production, which provide a wide range of provisioning, regulating and supporting ecosystem services that are essential to increase efficient use of natural resources (soil, water, air, fuel) and to realize environmental and food security goals in accordance with UNDP Sustainable Development Goals (Ghosh et al., 2019). It is estimated that at present, no-tillage is practiced on more than 105 million hectares worldwide however Notillage technology is practiced in South America; $37.8 \%$ is practiced in the United States and Canada, $11.5 \%$ in Australia and New Zealand and 3.7\% in the rest of the world, including Europe, Asia and Africa (Derpsch $e t$ al., 2010). Research over energy usage for different goods in agricultural production was conducted by several 
researchers. Marakoglu and Carman (2009) determined the energy balance of different tillage methods in chickpea production in their study. As a result, when the energy output and input ratios were examined, they found that; in direct planting + herbicide application, 1.604; in direct planting, 1.369; in the conventional application, 1.192 and in reduced tillage the ratio is 1.141, respectively. Altuntas et al. (2019) examined the effects of different tillage methods on energy while growing grain in the dry soil environment, in Sivas. As a result, concerning energy ratio, specific energy, energy productivity and energy-saving, direct planting, conservation tillage and reduced tillage can be used rather than conventional tillage. In the Second crop silage corn cultivation in the Mid-Black Sea Passage Zone, protected soil tillage, flat planting (KD) system is determined as more preferable than conventional tillage and applicable concerning energy resources and environmental protection (Altuntas et al., 2008).

This study aims to analyse the energy input-output of conventional tillage, reduced tillage and zero tillage. With the result of the data obtained in this study, it is aimed to use energy more efficiently, especially in corn production.

\section{Materials and Methods}

\section{Determination of the trial area}

The trials were conducted between 2015-2016 on the parcel connected to the General Directorate of Agricultural Enterprises numbered 160/1, located in Karatas in two regions of Ceylanpinar district of Sanliurfa. The satellite view of the trial area is shown in Figure 1.

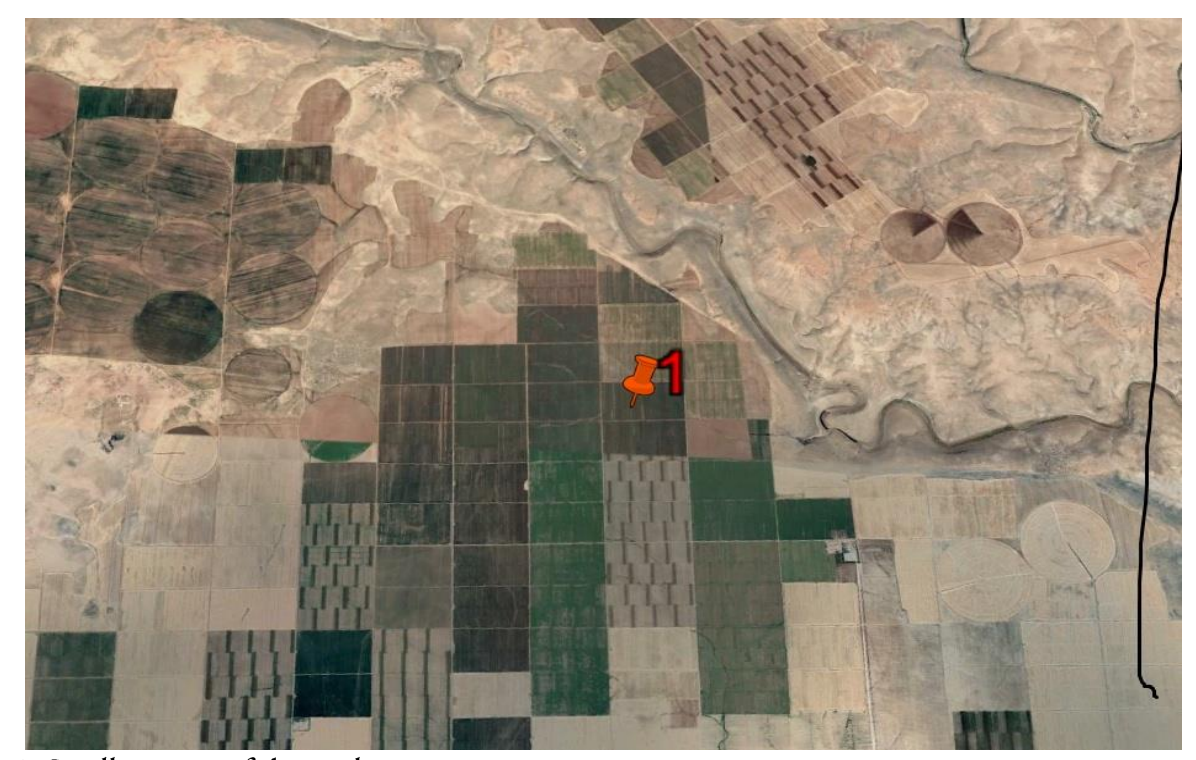

Figure 1. Satellite view of the trial area

\section{Machines used in the trial}

Some technical and dimensional specifications of agricultural equipment and machinery used in the trials are given in Table 1.

In the first application, conventional tillage (CT) was practiced using a moldboard plow + gobble disc harrow + pneumatic precision sowing machine for corn production. In the second application, reduced tillage (RT) was practiced using a double gobble disc harrow direct pneumatic precision seeder. In the third application, zero tillage (ZT) was practiced using a direct pneumatic precision sowing machine without soil tillage. 
Table 1. Technical specifications for agricultural equipment and machinery

\begin{tabular}{|c|c|c|c|}
\hline Machinery & $\begin{array}{c}\text { Number of } \\
\text { bodies }\end{array}$ & $\begin{array}{c}\text { Working width } \\
(\mathrm{cm})\end{array}$ & $\begin{array}{c}\text { Working } \\
\text { depth }(\mathrm{cm})\end{array}$ \\
\hline Moldboard plow & 8 & 320 & 25 \\
\hline Goble disc harrow & 40 & 440 & 15 \\
\hline Pneumatic precision seed drill & 6 & 420 & 4 \\
\hline Fertilizer intermediate hoeing machine & 6 & 420 & 4 \\
\hline Direct manure spreader & 8 & 560 & 4 \\
\hline Pneumatic precision direct seed drill - (No-Till) & 6 & 420 & 4 \\
\hline Spraying machine & - & 3200 & - \\
\hline Harvester & 5 & 350 & - \\
\hline
\end{tabular}

\section{Calculation of energy input-output}

Human labour energy, fuel and oil energy consumed by agricultural machines, irrigation energy and electricity energy for drying were evaluated as direct energy inputs. Tractor and Tool-Machine manufacturing energy, chemical fertilizer, seed production and energy consumed for pesticides used in the trial were evaluated as indirect energy inputs.

The following equations were used while calculating direct and indirect energy. The following equation is used for human labour energy.

\section{$H L E=H L \times U H L$} $\left(\mathrm{MJ} \mathrm{h}^{-1}\right)$

Here: HLE: Human labour energy (MJ ha $\left.{ }^{-1}\right)$, HL: Human labour $\left(h \mathrm{ha}^{-1}\right)$, UHL: Unit labour energy

The following equation is used for fuel energy.

$$
F E=F C \times F E E
$$
$\left(\mathrm{MJ} \mathrm{I}^{-1}\right)$

Here; FE: Fuel energy (diesel) $\left(\mathrm{Mj} \mathrm{ha}^{-1}\right)$, FC: Fuel consumption $\left(1 \mathrm{ha}^{-1}\right)$, FEE (Fuel energy equivalent

The following equation is used for machinery energy.

$M E=(W \times E) /(T \times E F C)$

Here: ME: Machine energy $\left(\mathrm{Mj} \mathrm{ha}^{-1}\right)$, W: Weight of the implement $(\mathrm{kg}), \mathrm{E}$ : manufacturing energy of the agricultural tractor or implements $\left(\mathrm{Mj} \mathrm{kg}^{-1}\right), \mathrm{T}$ : Economic life of the implement (h), EFC: Effective field capacity $\left(\right.$ ha $\left.h^{-1}\right)$

The coefficients in Table 2 are used for energy equivalents of input and outputs in agricultural production.

Table 2. Energy equivalents of inputs and outputs in corn production

\begin{tabular}{|c|c|c|}
\hline Inputs & $\begin{array}{c}\text { Energy equivalent } \\
\left(\text { MJ Unit }{ }^{-1}\right)\end{array}$ & References \\
\hline Unit human labor $(\mathrm{h})$ & 2.3 & (Baran et al., 2016; Barut et al., 2011) \\
\hline Diesel $(\mathrm{l})$ & 56.31 & (Kizlaslan, 2009; Mani et al., 2007) \\
\hline Water for irrigation $\left(\mathrm{m}^{3}\right)$ & 0.63 & (Barut et al., 2011) \\
\hline Agricultural machinery $(\mathrm{kg})$ & 121.3 & (Barut et al., 2011; Konak et al., 2004) \\
\hline Tractor $(\mathrm{kg})$ & 158.3 & (Barut et al., 2011) \\
\hline Nitrogen fertilizer $(\mathrm{kg})$ & 60.6 & (Bingh et al.,2008; Baran et al., 2016) et al., 2016; Barut et al., 2011) \\
\hline Phosphorus fertilizer $(\mathrm{kg})$ & 11.1 & (Baran et al., 2016) \\
\hline Herbicide $(\mathrm{kg})$ & 269 & (Barut et al., 2011) \\
\hline Seeds $(\mathrm{kg})$ & 104 & (Barut et al., 2011) \\
\hline Irrigation $\left(\mathrm{m}^{3}\right)$ & 0.63 & (Konak et al., 2004) \\
\hline Corn $(\mathrm{kg})$ & 14.58 & \\
\hline
\end{tabular}




\section{Energy effectiveness analysis}

In energy efficiency analysis, many researchers have performed calculations of energy use efficiency, energy productivity, specific energy and net energy generation (Barut et al., 2011; Baran et al., 2016; Altunta et al., 2019). The following equation is used for energy effectiveness.

Energy use efficiency $=$ Energy output $\left(\mathrm{Mj} \mathrm{h}^{-1}\right) /$ Energy input $\left(\mathrm{Mj} \mathrm{h}^{-1}\right)$

Energy productivity $\left(\mathrm{kg} \mathrm{Mj}^{-1}\right)=$ Product output $\left(\mathrm{kg} \mathrm{ha}^{-1}\right) /$ Energy input $\left(\mathrm{Mj} \mathrm{ha}^{-1}\right)$

Specific energy $\left(\mathrm{Mj} \mathrm{kg}^{-1}\right)=$ Energy input $\left(\mathrm{Mj} \mathrm{ha}^{-1}\right) /$ Product output $\left(\mathrm{kg} \mathrm{ha}^{-1}\right)$

Net energy $\left(\mathrm{MJ} \mathrm{ha}^{-1}\right)=$ Energy output $\left(\mathrm{MJ} \mathrm{ha}^{-1}\right)-$ Energy input $\left(\mathrm{MJ} \mathrm{ha}^{-1}\right)$

\section{Calculation of the total amount of energy input and output}

The sum of direct and indirect energy inputs was taken as total energy input. Used equation is given below.

$T E I=D E I+I E I$ $\left(\mathrm{Mj} \mathrm{ha}^{-1}\right)$

Here; FE: Total energy input $\left(\mathrm{Mj} \mathrm{ha}^{-1}\right)$, DEI: Direct energy input $\left(\mathrm{Mj} \mathrm{ha}^{-1}\right)$, IEI (Indirect energy input)

Output obtained from the second crop corn production was the corn yield. Total energy output was calculated by multiplying the amount of product per hectare $(\mathrm{kg})$ with the corn energy equivalent coefficient. Used equation is given below.

$$
T E O=T P \times 14.53
$$

Here: TEO: Total energy output $\left(\mathrm{Mj} \mathrm{ha}^{-1}\right)$, TP: Total product $\left(\mathrm{kg} \mathrm{ha}^{-1}\right)$

The equivalent coefficient value for corn grain was taken as $14.58 \mathrm{MJ} \mathrm{kg}^{-1}$ (Konak et al., 2004).

\section{Used inputs and the amount}

In the trials, 71 May 69 Fao - 650 group, second crop corn was used in South-eastern Anatolia Region, whose vegetation period was 123 - 125 days and seed known as main crop corn was used in other regions. In second crop corn production, $29.4 \mathrm{~kg}$ of sown norm corn seed was planted to the hectare.

In trials, $400 \mathrm{ml}$ of Mero EC 810 and 27 grams of Ekipp WG 61 herbicide were used and $4.3 \mathrm{~kg}$ total herbicide was applied to hectare for narrow and broadleaf weeds as an effective material in tillage applications.

Fertilizer DAP 18-46-0 di ammonium phosphate base fertilizer and 46\% Nitrogen Urea fertilizer were used. $205 \mathrm{~kg}$ nitrogen fertilizer and $104 \mathrm{~kg}$ phosphorus fertilizer were used for hectare.

In irrigation, $5178 \mathrm{~m}^{3}$ of water was used for hectare.

\section{Results}

\section{The determination of fuel consumption}

Fuel consumption of machinery and equipment was calculated for each work performed. The results obtained are given in Table 3.

When the fuel consumption values were examined, the highest fuel consumption was seen in the CT with $49.38 \mathrm{l} \mathrm{ha} 1$. This is $42.15 \%$ of the total fuel consumption. The lowest fuel consumption was seen in the ZT with $25.731 \mathrm{ha}^{-1}$ and, this was $21.96 \%$ of total fuel consumption.

\section{Total energy input}

To achieve the total energy input for different tillage methods, direct and indirect energy inputs are summed. Energy inputs for soil tillage applications and the ratio of this energy input to total inputs are given in Table 4. 
As Table 4 shows, among tillage methods, CT generated the highest energy input with $26919.74 \mathrm{Mj}$ ha ${ }^{1}$. This was followed by RT (26083.29 Mj ha' ${ }^{-1}$ ) and ZT (23724.15), respectively. The main reason for this could be the usage intensity of tillage tools and machinery. Among energy input parameters, fertilizer generally took the highest amount (CT 50.44\%, RT 52.06\%, ZT 57.23\%), this was followed by irrigation energy (CT 12.12\%, RT 12.51\%, ZT 13.75\%) and human labour energy had the lowest amount (CT 0.12\%, RT 0.10\%, ZT 0.07\%).

Table 3. Fuel consumption values

\begin{tabular}{|c|c|}
\hline \multicolumn{1}{|c|}{ Conventional tillage } & Fuel consumption $\left(\mathrm{l} \mathrm{ha}^{-1}\right)$ \\
\hline Agricultural equipment & 15.666 \\
\hline Moldboard plow & 9.111 \\
\hline Goble disc harrow & 7.301 \\
\hline Pneumatic precision seed drill & 5.298 \\
\hline Fertilizer intermediate hoeing machine & 1.800 \\
\hline Spraying machine & 10.198 \\
\hline Harvester & 49.38 \\
\hline Total value & \\
\hline Geduced tillage & 9.051 \\
\hline Goble disc harrow & 7.700 \\
\hline Goble disc harrow & 7.876 \\
\hline Pneumatic precision direct seed drill & 5.425 \\
\hline Direct manure spreader & 1.800 \\
\hline Spraying machine & 10.193 \\
\hline Harvester & 42.04 \\
\hline Total value & \\
\hline Stubble seed drill & 8.353 \\
\hline Direct manure spreader & 5.377 \\
\hline Spraying machine & 1.800 \\
\hline Harvester & 10.198 \\
\hline Total value & 25.73 \\
\hline
\end{tabular}

Table 4. Energy inputs obtained from corn production

\begin{tabular}{|c|c|c|c|c|c|c|c|}
\hline & CT & Rate (\%) & \multicolumn{7}{|c|}{ RT } & Rate (\%) & ZT & Rate (\%) \\
\hline & & \multicolumn{5}{|c|}{ Direct energy input $\left(\mathrm{Mj} \mathrm{ha}^{-1}\right)$} \\
\hline Fuel energy (diesel) & 2780.33 & 10.33 & 2367.14 & 9.08 & 1448.78 & 6.11 \\
\hline Human labour energy & 32.56 & 0.12 & 25.53 & 0.10 & 17.25 & 0.07 \\
\hline Irrigation energy & 3262.28 & 12.12 & 3262.28 & 12.51 & 3262.28 & 13.75 \\
\hline Total direct energy & 6075.17 & 22.57 & 5654.95 & 21.68 & 4728.31 & 19.93 \\
\hline Machine energy & 3052.87 & 11.34 & 2636.64 & 10.11 & 1204.14 & 5.08 \\
\hline $\begin{array}{c}\text { Nitrogen fertilizer } \\
\text { energy }\end{array}$ & 12423.00 & 46.15 & 12423.00 & 47.63 & 12423.00 & 52.36 \\
\hline $\begin{array}{c}\text { Phosphorus fertilizer } \\
\text { (kg) }\end{array}$ & 1154.40 & 4.29 & 1154.40 & 4.43 & 1154.40 & 4.87 \\
\hline Seed energy & 3057.60 & 11.36 & 3057.60 & 11.72 & 3057.60 & 12.89 \\
\hline $\begin{array}{c}\text { Agricultural spraying } \\
\text { energy (herbicide) }\end{array}$ & 1156.70 & 4.30 & 1156.70 & 4.43 & 1156.70 & 4.88 \\
\hline Total indirect energy & 20844.57 & 77.43 & 20428.34 & 78.32 & 18995.84 & 80.07 \\
\hline Total energy input & 26919.74 & 100 & 26083.29 & 100 & 23724.15 & 100 \\
\hline
\end{tabular}




\section{Total energy outcome}

Efficiency, which is the most important factor in comparing the methods, is an important parameter using energy output. Energy outputs for different tillage methods were examined in this work (Table 5).

The highest value among the energy outputs is seen in CT with $138510.00 \mathrm{MJ} \mathrm{ha}^{-1}$. This was followed by ZT (131365.80 $\left.\mathrm{MJ} \mathrm{ha}^{-1}\right)$ an RT (127575.00 $\left.\mathrm{MJ} \mathrm{ha}^{-1}\right)$, respectively (Table 5).

\section{Energy efficiency analysis results}

It is necessary to adopt new practices in soil preparation in our country's agriculture to use agricultural tools and machines with new technologies in soil tillage and to reduce product losses, more effective applications are necessary. Energy efficiency values were investigated separately for different tillage methods (Table 6).

Energy ratio or energy use efficiency is the most frequently used energy use efficiency criterion value. High energy efficiency value means that energy efficiency in production is high. Table 6 shows that the highest rate of energy use efficiency values was in ZT with 5.54. This was followed by CT (5.15) and RT (4.90), respectively.

The value of energy productivity (efficiency) indicates the amount of product produced $(\mathrm{kg})$ corresponding to the amount of unit energy (MJ) consumed. In other words, with the help of energy productivity (efficiency) values, it is determined how much product was $\mathrm{cx}$ obtained with the unit quantity of energy entering production. As presented in Table 6, the highest rate of energy productivity values was in ZT with $0.38 \mathrm{~kg} \mathrm{Mj}^{-1}$ This was followed by CT $\left(0.35 \mathrm{~kg} \mathrm{Mj}^{-1}\right)$ and $\mathrm{RT}\left(0.34 \mathrm{~kg} \mathrm{Mj}^{-1}\right)$, respectively.

Specific energy value shows the consumed amount of energy (MJ) to produce a product unit $(\mathrm{kg})$. Low specific energy value means that energy efficiency in production is high. 'The lowest rate of specific energy values was in ZT with $2.63 \mathrm{~kg} \mathrm{Mj}^{-1}$. This was followed by CT (2.83 MJ kg ${ }^{-1}$ ) and RT (2.98), as shown in Table 6 , respectively.

The higher the net energy efficiency is, the higher the energy efficiency in production is. As Table 6 shows, the highest rate of net energy values was in CT with $111590.26 \mathrm{Mj} \mathrm{ha}^{-1}$. This was followed by CT (107641.65 $\left.\mathrm{MJ} \mathrm{ha}^{-1}\right)$ and RT (101491.71 MJ ha $\left.{ }^{-1}\right)$, respectively.

Table 5. Energy outputs obtained from corn production

\begin{tabular}{|l|c|}
\hline \multicolumn{2}{|c|}{ Conventional tillage } \\
\hline Corn yield $\left(\mathrm{kg} \mathrm{ha}^{-1}\right)$ & 9500 \\
\hline Total energy output $\left(\mathrm{MJ} \mathrm{ha}^{-1}\right)$ & 138510.00 \\
\hline \multicolumn{2}{|c|}{ Reduced tillage } \\
\hline Corn yield $\left(\mathrm{kg} \mathrm{ha}^{-1}\right)$ & 8750 \\
\hline Total energy output $\left(\mathrm{MJ} \mathrm{ha}^{-1}\right)$ & 127575.00 \\
\hline \multicolumn{2}{|c|}{ Zero tillage } \\
\hline Corn yield $\left(\mathrm{kg} \mathrm{ha}^{-1}\right)$ & 9010 \\
\hline Total energy output $\left(\mathrm{MJ} \mathrm{ha}^{-1}\right)$ & 131365.80 \\
\hline
\end{tabular}

Table 6. Energy efficiency results

\begin{tabular}{|c|c|c|c|}
\hline Parameters & CT & RT & ZT \\
\hline Energy use efficiency & 5.15 & 4.90 & 5.54 \\
\hline Energy productivity $\left(\mathrm{kg} \mathrm{M}^{-1}\right)$ & 0.35 & 0.34 & 0.38 \\
\hline Specific energy $\left(\mathrm{Mj} \mathrm{kg}^{-1}\right)$ & 2.83 & 2.98 & 2.63 \\
\hline Net energy $\left(\mathrm{MJ} \mathrm{ha}^{-1}\right)$ & 111590.26 & 101491.71 & 107641.65 \\
\hline
\end{tabular}




\section{Discussion}

In Table 3, ZT (25.73 $\left.1 \mathrm{ha}^{-1}\right)$, RT (42.04 $\left.1 \mathrm{ha}^{-1}\right)$ and CT $\left(49.38 \mathrm{l} \mathrm{ha}^{-1}\right)$ results were obtained in fuel consumption. The similar results were obtained in the studies conducted on this subject. Cakir et al. (2006) stated that direct planting and no-tillage methods had eight times less fuel consumption and six times more job success compared to conventional applications. Application in direct seeding is zero tillage in which no-tillage is made during the whole vegetation period of the plant. In this method, $40 \%$ of energy is saved (Aykas et al., 2005). The highest fuel consumption was measured in the conventional method (PLG), whereas the lowest value was found in direct seeding method (DIR) as $60.51 \mathrm{ha}^{-1}$ and $7.51 \mathrm{ha}^{-1}$ in 2002 , respectively. The conventional method required seven times more fuel than the direct seeding method (Yalcin and Cakir, 2006). As can be seen from the obtained results, the lowest fuel consumption in 2002, 2005, 2008 was 11.91, 10.24 and $11.57 \mathrm{l} \mathrm{ha}^{-1}$ with no-till seeding, respectively (Gozubuyuk et al., 2010). Lithourgidis et al. (2005) found that in no-tillage and reduced tillage methods in silage corn production was total time saving $35.9 \%, 5.6 \%$ and total fuel saving $36.0 \%, 7.2 \%$, respectively.

In Table 4, ZT (23724.15 MJ ha-1), RT (26083.29 $\mathrm{Mj} \mathrm{ha}^{-1}$ ) and CT (26919.74 $\mathrm{Mj} \mathrm{ha}^{-1}$ ) results were obtained in total energy inputs. Among the energy input parameters, fertilizer had the highest value, followed by irrigation energy and human energy. The similar results were obtained in the studies conducted on this subject. Fertilizer energy had the highest share of production inputs in all methods, with $13552.50 \mathrm{MJ} \mathrm{ha}{ }^{-1}$ (Baran et al., 2016). Bilalis et al. (2013) stated that the energy input for corn and tomato in conventional tillage was higher than that in organic tillage and this rate was $25.90 \%$ for tomato and $29.34 \%$ for corn. Celen et al. (2017) conducted energy input-output analysis in apple cultivation. Consequently, they stated that the highest energy consumption among the general energy inputs was fertilizer energy, fuel-oil energy, chemicals, machinery, human labor and irrigation energy, respectively. In corn production, fertilizer energy has the highest rate of utilization among total input energies. This was followed by seeds, tool and machinery and fuel and oil energy, respectively. Abbas et al. (2018) have stated that the biggest input for optimum energy requirement in corn production is fertilizer input with $14760.24 \mathrm{MJ} \mathrm{ha}^{-1}$ and that if farmers use energy efficiently, this value can be saved by $17.11 \%$. Mortaza et al. (2012) analyzed energy use for corn production in Iran. As a result, they noted that the total energy input for corn production was $392323 \mathrm{MJ} \mathrm{ha}^{-1}$, and $44 \%$ of this was chemical fertilizer and $27 \%$ was electricity. Jacobs et al. (2016) reported that 33-48\% of total energy input in silage maize production was chemical fertilizer and $34-40 \%$ of it was fuel-oil energy. Kosutic et al. (2005) reported that fuel energy inputs in conventional tillage, protective tillage and stubble direct sowing applications are $1813.1,1133.1$ and $270.1 \mathrm{MJ} \mathrm{ha}^{-1}$, respectively.

In Table 5, CT (138510.00 MJ ha'), ZT (131365.80 $\mathrm{MJ} \mathrm{ha}^{-1}$ ) and RT (127575.00 $\mathrm{MJ} \mathrm{ha}^{-1}$ ) results obtained in total energy output. The main reason for this is the higher yield in CT. Barut et al. (2011) found that the energy output of the second crop silage corn production was $232354.08 \mathrm{MJ} \mathrm{ha}^{-1}$ in conventional tillage and $197585.92 \mathrm{MJ} \mathrm{ha}^{-1}$ in direct-sowing (no-till) application. Konak et al. (2004) determined the energy output in traditional corn production in Konya as $102060 \mathrm{MJ} \mathrm{ha}^{-1}$. Dalgaard et al. (2001) reported that energy efficiency in organic farming was higher than conventional agriculture, but the yields were lower.

The energy efficiency values obtained in Table 6 are similar to many studies. In a study conducted by Oren and Ozturk (2006) on wheat, in Southeast Anatolia Region, the energy rate was found to be 2.21, the specific energy value was $7.18 \mathrm{MJ} \mathrm{kg}^{-1}$, and the energy productivity was $0.14 \mathrm{~kg} \mathrm{MJ}^{-1}$. Khaledian et al. (2010) found that the energy value required for the production of $1 \mathrm{~kg}$ of corn is $2 \mathrm{MJ} \mathrm{kg}^{-1}$ for conventional and direct planting. Baran et al. (2016) found that net energy productivity in corn production was (198190.21 $\mathrm{Mj} \mathrm{ha}^{-1}$ ) in reduced soil tillage and $\left(179699.04 \mathrm{Mj} \mathrm{ha}^{-1}\right)$ in direct planting. The average yield of the maize crop was determined to be $6600 \mathrm{~kg} \mathrm{ha}^{-1}$ with an energy ratio of 3.8 and the specific energy of $3.88 \mathrm{MJ} \mathrm{kg}^{-1}$ (Canakci et al., 2005). The energy values were found by Canakci et al. (2005) to be lower than our results. The reason for this is that the yield was lower than the values we obtained. 
Barut et al. (2011) found that the highest benefit/cost ratio and productivity were 2.13 in reduced tillage and 2.07 in direct planting (no-tillage) in their study on the use of energy in different tillage methods in second crop corn production. As a result, they emphasized that reduced soil tillage (RT) and direct planting methods (ZT) should be supported concerning energy profitability and sustainability. Kumar et al. (2013) found that the energy productivity of wheat production in irrigated conditions in the Indo-Gangetic Plains was $0.176 \mathrm{~kg}$ $\mathrm{MJ}^{-1}$ in traditional practice and $0.222 \mathrm{~kg} \mathrm{MJ}^{-1}$ in direct sowing. Cikman et al. (2010) examined the effects of different tillage methods on productivity in corn and cotton in the Harran Plain. As a result, they stated that the productivity was high in the reduced tillage and non-tillage methods and with the decrease in the need for inputs (fuel, time, labour force), an increase was observed in income.

\section{Conclusions}

As a result, compared to conventional tillage, reduced tillage especially zero tillage, it needs higher inputs in terms of machinery investment, maintenance-repair, labour force and causes high carbon emissions. Therefore, zero tillage and reduced tillage methods should be supported due to their high energy efficiency and environmental friendliness.

\section{Acknowledgements}

This research received no specific grant from any funding agency in the public, commercial, or not-forprofit sectors.

\section{Conflict of Interests}

The authors declare that there are no conflicts of interest related to this article.

\section{References}

Abbas A, Yang M, Yousaf K, Ahmad M, Elahi E, Iqbal T (2018). Improving energy use efficiency of corn production by using data envelopment analysis (a non-parametric approach). Fresenius Environmental Bulletin 27(7):47254733.

Altuntas E, Bulut ON, Ozgoz E (2019). Energy use efficiency analysis of wheat production with different soil tillage systems in dry agriculture. Anadolu Journal of Agricultural Sciences 34(1):57-64.

Altuntas E, Ozgoz E, Dede S (2008). Effect of the different tillage systems on energy use efficiency of second crop silage maize in Mid-Black Sea transition climate belt. Selcuk Journal of Agriculture and Food Sciences 32(3):238-248.

Aykas E, Yalcın H, Cakır E (2005). Conservation tillage methods and direct seeding. Journal of Agriculture Faculty of Ege University 42(3):195-205.

Baran MF, Karaagac HA, Gokdogan O (2016). Energy balance of different soil tillage and planting methods on the secondary crop silage corn production, planted after the winter catch crop (wheat - vetch mixture) (2nd year results). Journal of Adnan Menderes University Agricultural Faculty 13(1):1-6.

Barut ZB, Ertekin C, Karaagac HA (2011). Tillage effects on energy use for corn silage in Mediterra-nean coastal of Turkey. Energy 36(9):5466-5475.

Bilalis D, Kamariari PE, Karkanis A, Efthimiadou A, Zorpas A, Kakabouki I (2013). Energy inputs, output and productivity in organic and conventional maize and tomato production, under Mediterranean conditions. Notulae Botanicae Horti Agrobotanici Cluj-Napoca 41(1):190-194. 
Cakir, E, Yalcin H, Aykas E, Gulsoylu E, Okur B, Delibacak S, Ongun AR (2006). The effect of conservation tillage in direct seeding applications on the yield of second crop maize. Journal of Agricultural Machinery Science 2(2):139146.

Canakci M, Topakci M, Akinci I, Ozmerzi A (2005). Energy use pattern of some field crops and vegetable production: case study for Antalya region, Turkey. Energy Conversion and Management 46(4):655-666.

Celen IH, Baran MF, Onler E, Bayhan Y (2017). Determination of energy balance of apple (Malus domestica) production in Turkey: a case study for Tekirdag province. Anadolu Journal of Agricultural Sciences 32(1):40-45.

Cikman A, Monis T, Saglam R, Nacar AS (2010). Application of reduced soil tillage and non-tillage agriculture techniques in Harran plain (second crop maize and sesame growing). Journal of Agricultural Machinery Science 6(4):221228.

Dalgaard T, Halberg N, Porter JR (2001). A model for fossil energy use in Danish agriculture used to compare organic and conventional farming. Agriculture, Ecosystems and Environment 87(1):51-65.

Derpsch R, Friedrich T, Kassam A, Hongwen L (2010). Current status of adoption of no-till farming in the world and some of its main benefits. International Journal of Agriculture and Biological Sciences 3(1):1-25.

Ghosh S, Das TK, Sharma D, Gupta K (2019). Potential of conservation agriculture for ecosystem services: A review. Indian Journal of Agricultural Sciences 89(10):1572-1579.

Gozubuyuk Z, Ozturk, I, Demir O, Celik A (2010). Comparison of various tillage-seeding systems for sunflower production in terms of some operating parameters. Journal of Agricultural machinery Science 6(4):253-259.

IEA (2019). IEA. Retrieved June, 2019 from https://www.iea.org/topics/energyefficiency/

Iqbal T (2007). Energy input and output for production of Boro rice in Bangladesh. Electronic Journal of Environmental, Agricultural and Food Chemistry 6(5):2144-2149.

Jacobs A, Siebrecht WB, Christen O, Gotze P, Koch HJ, Rucknagelb J, Marlander B (2016). Silage maize and sugar beet for biogas production in crop rotations and continuous cultivation - energy efficiency and land demand. Field Crops Research 196:75-84.

Khaledian MR, Mailhol JC, Ruelle P, Mubarak I, Perret SR (2010). The impacts of direct seeding into mulch on the energy balance of crop production system in the SE of France. Soil and Tillage Research 106(2):218-226.

Kizilaslan H (2009). Input-output energy analysis of cherries production in Tokat Province of Turkey. Applied Energy 86(7-8):1354-1358.

Konak M, Marakoglu T, Ozbek O (2004). Energy balance at corn production. Selcuk Journal of Agriculture and Food Sciences 18(34):28-30.

Kosutic S, Filipovic D, Gospodaric Z, Husnjak S, Kovacev I, Copec K (2005). Effects of different soil tillage systems on yield of maize, winter wheat and soybean on albic luvisol in North-West Slavonia. Central European Agriculture 6(3):241-248.

Kumar V, Saharawat Y, Gathala MK, Jat AS, Singh SK, Chaudhary N, Jat M (2013). Effect of different tillage and seeding methods on energy use efficiency and productivity of wheat in the Indo-Gangetic Plains. Field Crops Research 142:1-8.

Lithourgidis AS, Tsatsarelis CA, Dhima KV (2005). Tillage effects on corn emergence, silage yield, and labour and fuel inputs in double cropping with wheat. Crop Science 45(6):2523-2528.

Mani I, Kumar P, Panvar JS, Kant K (2007). Variation in energy consumption in production of wheat-maize with varying altitudes in hilly regions of Himachal Pradesh, India. Energy 32(12):2336-2339.

Marakoglu T, Carman K (2009). Nohut tarımında farklı üretim tekniklerinin enerji bilançosu. Selcuk Journal of Agriculture and Food Sciences 23(48):47-50.

Morteza T, Mobtaker HG, Monjezi N (2012). Energy input-output modelling and economical analyse for corn grain production in Iran. Elixir Agriculture 52(11):11500-11505.

Oren MN, Ozturk HH (2006). An analysis of energy utilization for sustainable wheat and cotton production in Southeastern Anatolia Region of Turkey. Journal of Sustainable Agriculture 29(1):119-130.

Singh KP, Prakash V, Srinivas K, Srivastava AK (2008). Effect of tillage management on energy-use efficiency and economics of soybean (glycine max) based cropping systems Under the rainfed conditions in North-West Himalayan Region. Soil and Tillage Research 100(1-2):78-82.

Yalcin H, Cakir E (2006). Tillage effects and energy efficiencies of subsoiling and direct seeding in light soil on yield of second crop corn for silage in Western Turkey. Soil and Tillage Research 90(1-2):250-255. 
The journal offers free, immediate, and unrestricted access to peer-reviewed research and scholarly work. Users are allowed to read, download, copy, distribute, print, search, or link to the full texts of the articles, or use them for any other lawful purpose, without asking prior permission from the publisher or the author.

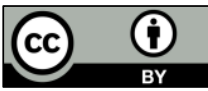

License - Articles published in Notulae Scientia Biologicae are Open-Access, distributed under the terms and conditions of the Creative Commons Attribution (CC BY 4.0) License.

(c) Articles by the authors; SHST, Cluj-Napoca, Romania. The journal allows the author(s) to hold the copyright/to retain publishing rights without restriction. 